\title{
Monoxyl a další dřevěné struktury v oblasti řeky Moravy z lokalit Moravičanských jezer na katastru Mohelnice
}

\author{
Monoxylon and other wooden structures in the Morava River \\ region from the sites of Moravičany Lakes in the Mohelnice cadastre
}

- Jaroslav Peška*-

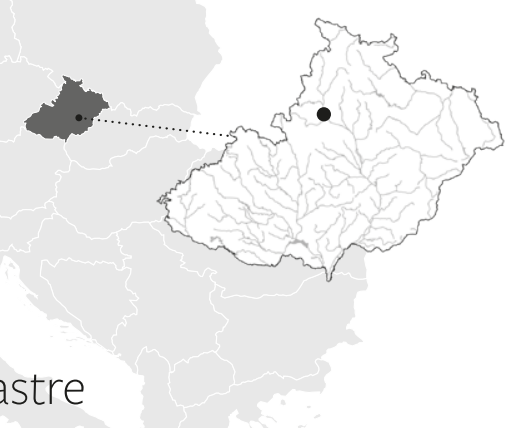

\section{KEYWORDS:}

monoxylon - wooden constructions - timber trackway dendrochronology - La Tène period - early modern period

\section{ABSTRACT}

The article presents a brief summary of newly discovered wooden structures in the well-known polycultural site Mohelnice - štěrkovna (also "U cukrovaru" or Za cukrovarem) in the Mohelnice cadastre and its vicinity. Earlier discoveries at this site include Neolithic timbered wells and a sensational find of an oak monoxylon from the La Tène period of the $4^{\text {th }} / 3^{\text {rd }}$ century BC (dendro 281 or $301 \mathrm{BC}$ ). It was found trapped in its home port on the banks of the meandering river Morava and dating has revealed the same age as the absolutely dated simple wooden pole construction. It is the northernmost found monoxylon known in the Czech Republic and also presents the oldest evidence for such use of ships on Czech rivers. The manufacture and use of such ships has been known since the Mesolithic period continuing until modern times. The subsequent exploration of the shores of the Moravičany Lakes banks revealed a number of smaller wooden structures below the water surface, either made up of pointed stakes themselves, or a combination of smaller stakes and branches built into a tapered corridor resembling a structure used for fishing. The latest discovery is a massive oak-fir structure manufactured from stakes, longitudinal and transverse planks and stones, interpretable as a timber trackway, or a bridge. It has been dendrochronologically dated to 1547-1560 and archival sources indicate the structure was repaired in 1645. The structure spans the former meander between Třeština and Mohelnice near one of the mills. The existence of this route is documented on $18^{\text {th }}$-century maps. Significant discoveries from various times of mainly wooden buildings underscore at least the European significance of the Mohelnice site. It may yield many valuable finds in the future.

\footnotetext{
* Corresponding author-E-mail address: peska@ac-olomouc.cz

Otvíráme-li novodobou kapitolu v dějinách archeologických výzkumů v Mohelnici, musíme se opět vrátit do blízkosti proslulé pravěké lokality Mohelnice - štěrkovna (zvané též „U cukrovaru“ nebo „Za cukrovarem“), jíž je věnována právě vycházející monografie (Stuchlík, Tichý et al. v tisku). Polykulturní naleziště se zcela výjimečným nálezovým potenciálem (především roubené studny a jejich obsah) prostorově nejspíše souvisí s tratí „Bartošovo pole“ s nálezy z neolitu (LnK) a eneolitu (KNP, MŠK), situovanou o něco jižněji rovněž v poloze „Za cukrovarem“. Plochu výzkumu Rudolfa Tichého se nám podařilo přibližně lokalizovat do jihozápadního cípu dnešní mohelnické štěrkovny a částečně na její ještě neodtěžený břeh (obr. 1).

$\mathrm{Na}$ opačném (východním) břehu jezera ve vzdálenosti cca 800 m (trat', U Moravy“ - obr. 1) došlo v červnu 1999 v blíz kosti (cca $70 \mathrm{~m}$ ) dnešního regulovaného toku řeky Moravy ke zcela mimořádnému objevu dlabané lodi a několika zahrocených kůlů z doby laténské (rozhraní 4. a 3. století před n. 1.), která přídí vyčnívala z vody a zádí byla zabořena do náplavových sedimentů. Bezprostředně po nálezu byla zorganizována na místě záchranná akce Vlastivědného muzea v Olomouci (21.-24. června), jejímž výsledkem se stal unikátní objev lodi vydlabané z jednoho kusu kmene - monoxylu (Peška 1999a; 1999b; 2000; Peška, Kučerová 2002; Kučerová, Peška 2004).

V průběhu technicky i organizačně vysoce náročného záchranného výzkumu (odvíření za pomocí remorkéru, odtěžení sedimentu strojem UDS: obr. 2, 3) bylo zjištěno, že lod' je uložena dnem vzhůru, přičemž její menší zadní část spočívá pod vodou a směřuje šikmo do hloubky pod štěrkopískové a jílové sedimenty. Přitom bylo $\mathrm{v}$ bezprostřední blízkosti přídě a posléze i zádi tělesa zaznamenáno několik dřevěných kůlů o průměru zhruba $20 \mathrm{~cm}$. Po odsunutí kořene mohutného stromu a odkopání sedimentů do hloubky nejméně $1 \mathrm{~m}$ pod dnešní hladinou se postupně podařilo obnažit celý trup lodi. Nedaleko zádi se podařilo zdokumentovat nepravidelnou řadu celkem 5 dřevěných opracovaných kůlů (K 1 - K 5). Mezi dva prostřední (K 2, K 3) byla zád' lodi zaklíněna (obr. 4). V této souvislosti je nutno připomenout, že přídí se trup lodi o jeden z kủlů (K 6) doslova opíral a v nevelké vzdálenosti od něj jsme nalezli další dva kůly v poloze vytvářející dojem další řady v přední linii objektu (obr. 5). Vzdálenost obou řad kůlů činila asi 6-7 m. Nálezová situace navozuje myšlenku o uložení monoxylu na původním místě jakéhosi úvaziště nebo přístavu, kde $\mathrm{k}$ převrácení mohlo dojít $\mathrm{v}$ důsledku nám blíže neznámé události (povodňová vlna?). Tuto teorii podporují jasné stopy po uvazování na těle jednoho z vyzvednutých kůlů (obr. 10). Z důvodu př́pravy objektu na vytažení z vody a pro definitivní potvrzení nálezu byl předmět ve vodě posunut zhruba o jeden metr dopředu a pak otočen o $180^{\circ}$. Pro neschůdnost terénu, resp. nepř́stupnost přilehlého břehu štěrkovny byl objekt ponechán prozatím na místě nálezu. 


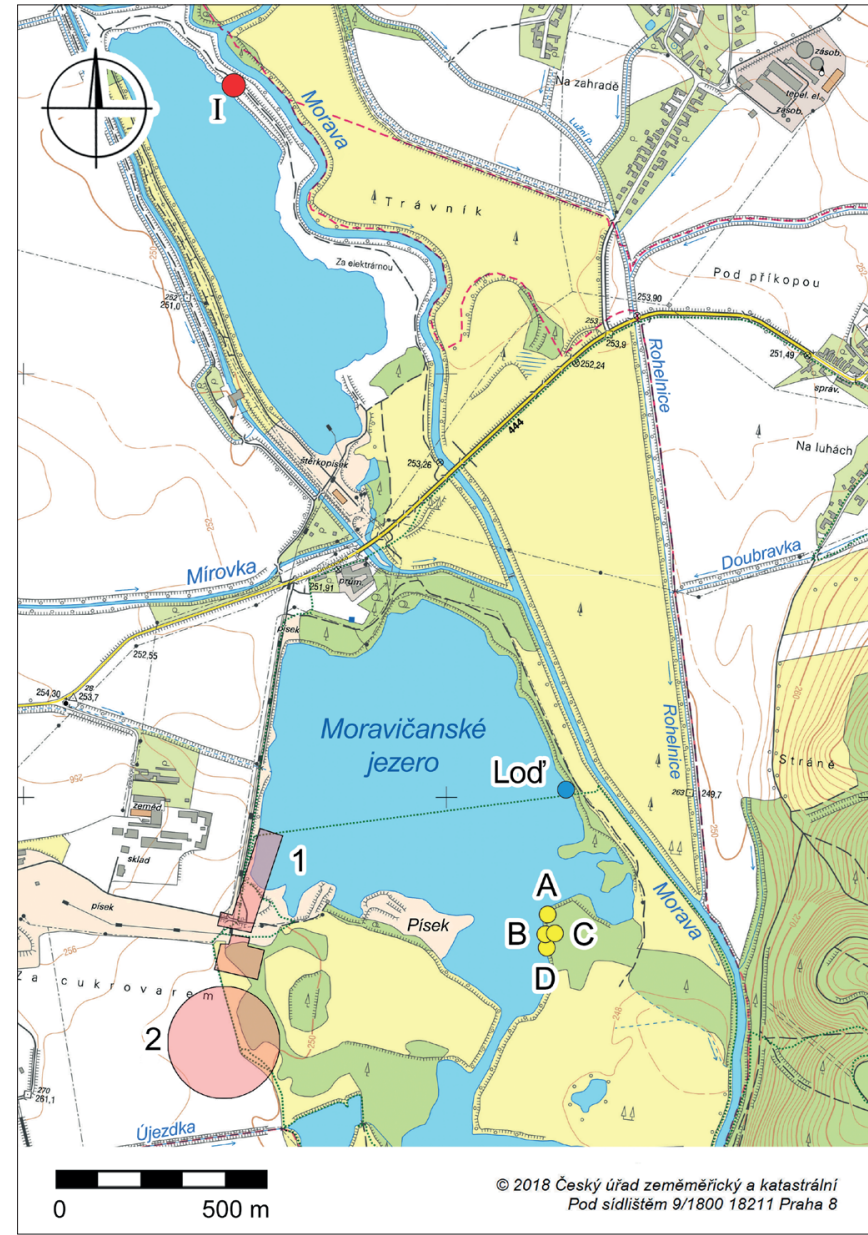

Obr. 1. Mapa části katastru Mohelnice podél toku řeky Moravy s vybranými archeologickými lokalitami. 1 - Mohelnice „Za cukrovarem“, „U cukrovaru“ - plochy výzkumu R. Tichého 1953-1971; 2 - Mohelnice „Za cukrovarem“, „Bartošovo pole“; Lod’ Mohelnice „U Moravy“ 1999 - místo nálezu monoxylu z doby laténské; A-D - Mohelnice „U Moravy“ 2001-2003 - dřevěné blíže nedatované struktury; I - Mohelnice „Za Moravou“ 2006 - místo objevu dřevěného mostu nebo lávky z2. poloviny 16. století. Mapa P. Grenar.

Fig. 1. Map of a part of the Mohelnice cadastre alongside the Morava River with selected archaeological sites. 1 - Mohelnice "Za cukrovarem", "U cukrovaru”- areas excavated by R. Tichý, 1953-1971; 2 - Mohelnice "Za cukrovarem", "Bartošovo pole"; Boat Mohelnice "U Moravy" 1999 - the site of discovery of the monoxylon from the La Tène period; A-D - Mohelnice "U Moravy" 2001-2003 - wooden structures without more precise dating; I - Mohelnice "Za Moravou" 2006 - the site of discovery of a wooden bridge or a footbridge from the $2^{\text {nd }}$ half of the $16^{\text {th }}$ century. Map by P. Grenar.

Následujícího dne, opět za přispění pracovníků Štěrkopískovny Mohelnice, ale také Hasičského záchranného sboru okresu Olomouc, ${ }^{1}$ byla lod' ve vodě nadlehčena speciálními nafukovacími nornými stěnami tak, aby nemohlo během transportu dojít k jejímu poškození, a opatrně přeplavena na protější přístupný břeh jezera (obr. 7). Po vytažení byl objekt kresebně zdokumentován (obr. 6) a za veškerých bezpečnostních opatření transportován do Vlastivědného muzea v Olomouci k velmi náročné konzervaci. $^{2}$

Lod' vydlabaná z jednoho kusu kmene dubu (Quercus sp.) $)^{3}$ překvapuje svou mohutností a ladností zároveň. Trup má velmi mírný kónický tvar s maximální šířkou v zadní čtvrtině. Př́íd je slabě asymetricky zahrocena a ukončena rovnou ploškou. V levé polovině je opatřena kruhovým otvorem, patrně zbytkem úvazu pro kotvení, ale také tahání lodi. Zád’ je upravena do tvaru ploché nepatrně se zužující obdélné plošiny. Na její pravé straně rozeznáváme čtvercové či spíše úzké obdélné (předmět v tomto místě porušen) vybrání, což nevylučuje původní místo pro kormidlo (?). Vnitřek lodi je rozdělen celkem 4 prŕíňnými žebry

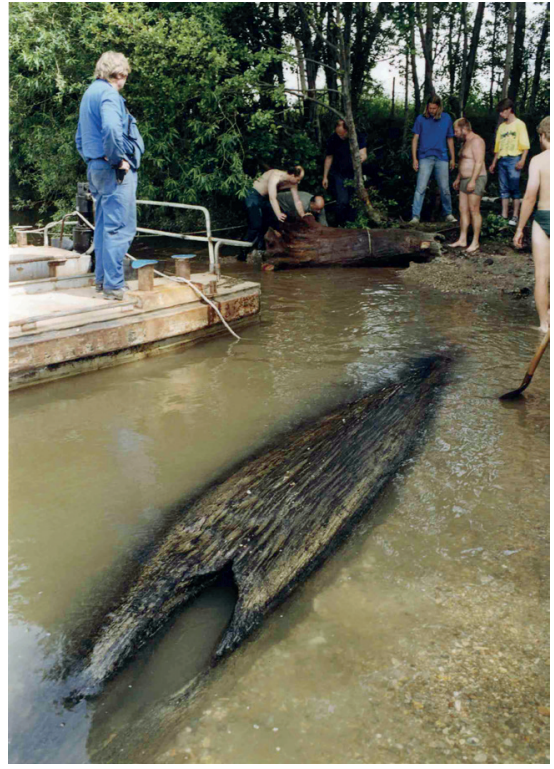

Obr. 2. Mohelnice „U Moravy“ 1999. Záchranný výzkum monoxylu za pomoci remorkéru. Foto archiv ACO (Archeologické centrum Olomouc).

Fig. 2. Mohelnice "UMoravy" 1999. Rescue excavation of the monoxylon using a tugboat. Photo archive ACO (Archeologické centrum Olomouc).

umístěnými rovnoměrně po celé délce. Ta mohla sloužit bud' jako výztuha nebo by se mohlo jednat o kontrolní body při dlabání či úpravě dna lodi ( $c f$. Arnold 1995, 49 ad.). O dovednosti tehdejších stavitelů nás přesvědčuje účelné oboustranně půlkruhové zakončení vlastního trupu, stejně jako dokonale vypracovaná spodní část lodi. Prvotním trasologickým pozorováním (P. Růžička) byly na plášti lodi sledovány stopy po bronzových, příp. železných nástrojích (sekerách). ${ }^{4}$ Lod' má délku 10,5 m, maximální šířku 1,05 m a je 0,6 m vysoká (obr. 9), síla zachovaného dřeva se pohybuje v rozmezí 3,1-18 cm. Podle J. Rogerse (2004) měla hmotnost $1094 \mathrm{~kg}$, ponor 17,5 cm, nosnost $1077 \mathrm{~kg}$ a mohla nést posádku o 18 členech.

Lodě dlabané z jednoho kusu kmene pamatuje lidstvo již od stř̌ední doby kamenné (mezolitu), kdy jsou známy nálezy např. z území dnešního Holandska. Celkem běžně se objevují v neolitu a eneolitu od Skandinávie po Středomoří, mladší exempláře pocházejí z doby bronzové, obou period doby železné i z doby římské (Arnold 1995). Výrazné je jejich používání starými Slovany, ale také ve stř̌edověku a místně se udržely až do současnosti (např. stř̌ední Švýcarsko, Horní Rakousko). U nás např. v Čechách

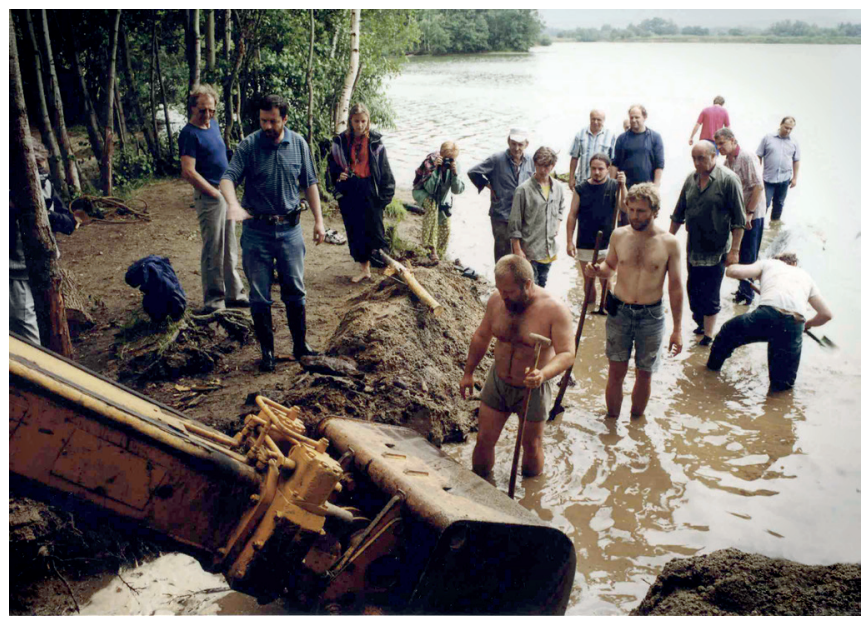

Obr. 3. Mohelnice „U Moravy“ 1999. Odstraňování povodňových sedimentů nad zádí lodi těžkou technikou. Foto archiv ACO.

Fig. 3. Mohelnice "U Moravy" 1999. Removal of flood sediments above the stern of the boat using heavy equipment. Photo archive ACO. 


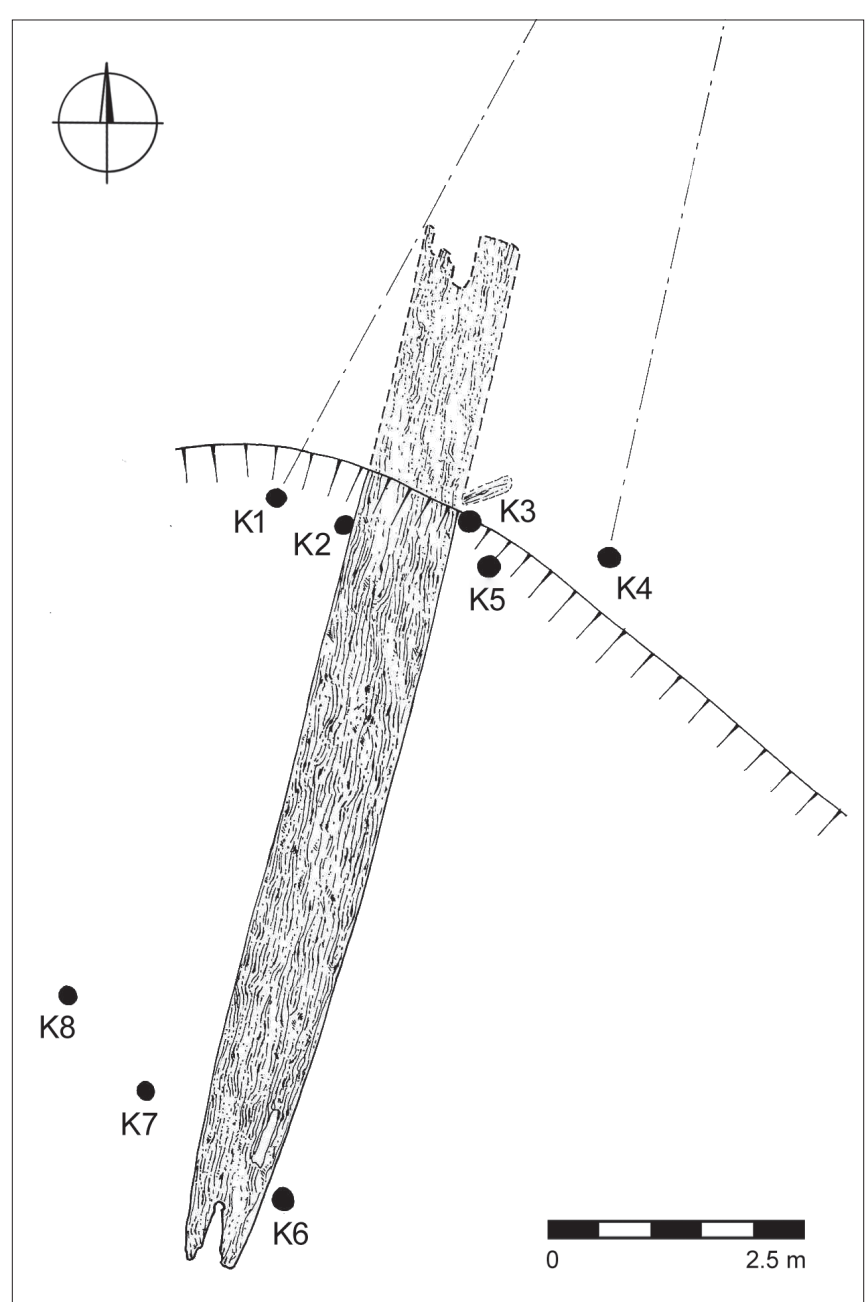

Obr. 4. Mohelnice „U Moravy“ 1999. Nálezová situace monoxylu mezi dvěma řadami kůlů. Kresba A. Pešková.

Fig. 4. Mohelnice "U Moravy" 1999. Find context of the monoxylon between two rows of stakes. Drawing by A. Pešková.

na Orlici, kde se objevují až do 19. století, na severním Slovensku do počátku 20. století a na Dunajci se údajně jednoduché čluny používají dodnes (Novotný 1986, 570). Kromě Evropy byly zaznamenány také v Asii, Africe nebo Americe. Jejich délka se pohybuje mezi 2-30 m, a pokud se týká tvaru, nelze zde ve vztahu $\mathrm{k}$ chronologii uplatnit prakticky žádnou typologickou metodu. Tato skutečnost samozřejmě ztěžuje otázku datování.

Na území České republiky se nálezy koncentrují v Čechách do Polabí a částečně do Pojizeří a na horní tok Bíliny (Přerov nad Labem, Kolín, Čelákovice, Labětín, Oseček, Poděbrady, Ervěnice, Dolní a Horní Jiřetín) a jsou převážně datovány do raného středověku. Všechny jsou z dubu, s výjimkou posledního zatím blíže nedatovaného nálezu u Skorkova na Jizeře (2002), který byl vyroben z kmene jedle bělokoré (Špaček 2002; Šilhová, Špaček 2004). Na Moravě je známe hlavně z dolního toku stejnojmenné řeky ze Spytihněvi, Starého Města, Uherského Hradiště, Kostelan nad Moravou, Bzence, Veselí nad Moravou a Rohatce, včetně čtyř exemplářơ z velkomoravských Mikulčic (Tichý 2002; Poláček et al. 2000) s jedním absolutním datem minimálně z 1. poloviny 9. století (Poláček et al. 2000, 206). Ostatní čluny jsou spíše tradičně řazeny do raného středověku (Hrubý 1949). Geograficky nejbližší je Mohelnici nález jednomístného krátkého člunu z meandru řeky Moravy u Př́íkaz-Hynkova (analogie se člunem ze Spytihněvi), datovaný nově dendrochronologicky po roce 1537 (laskavá informace R. Fraita). Přesto zůstává mohelnický monoxyl nejsevernějším moravským nalezištěm.

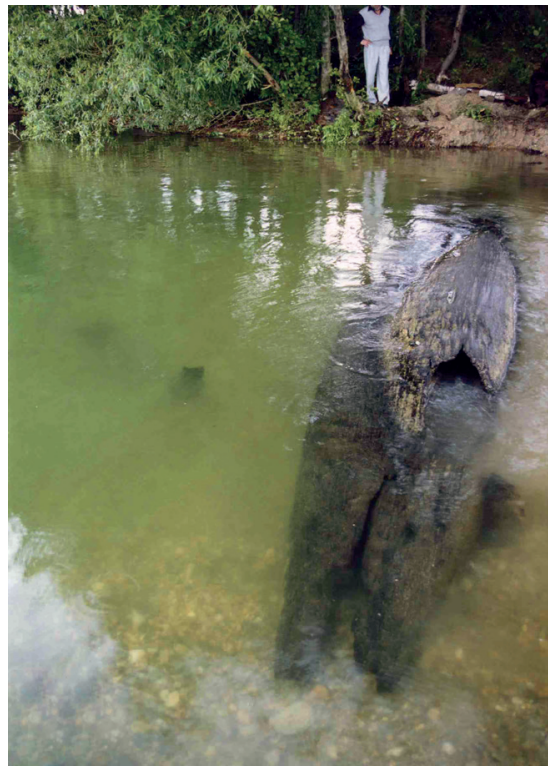

Obr. 5. Mohelnice „U Moravy“ 1999. Nálezová situace monoxylu na břehu štěrkovny. $U$ prí́dě řada kůlů. Foto archiv ACO.

Fig. 5. Mohelnice "U Moravy" 1999. Find context of the monoxylon on the banks of the gravel pit reservoir A row of stakes near the bow. Photo archive ACO.

Relativně časté jsou dlabané čluny v Poodří v Polsku, a to prakticky po celé délce toku. Rovněž jejich datování je značně široké, převládají však plavidla středověká (Filipowiak 1995). Nedávno zveřejněným objevem $v$ této oblasti je přes $12 \mathrm{~m}$ dlouhý člun z naleziště Lewin Brzeski nedaleko Opole v Horním Slezsku, náležící do mladší doby římské (373 A.D.) (Babiński 1999). Tvarem i velikostí podobné lodě najdeme opět na velice širokém teritoriu prakticky celé Evropy, za všechny uved'me alespoň novější objev člunu na dně jezera Bracciano, lokalita La Marmotta 1 nedaleko Ríma, datovaný do neolitu (Fugazzola Delpino, Mineo 1995), stejně jako deset monoxylů z Bercy u Paříže (Barthez et al. 1999) a mohli bychom jmenovat celou řadu dalších příkladů lodí stejného typu (Arnold 1995).

Stáŕí mohelnické lodi jsme se pokusili stanovit za pomoci kombinace více metod absolutního datování. Kromě dnes již klasické metody pomocí rozpadu radioaktivního uhlíku ${ }^{14} \mathrm{C}$ byly odebrány vzorky na dendrochronologickou analýzu. Přestože první výsledky datování pomocí metody ${ }^{14} \mathrm{C}$ (PřF UK Praha $2965 \pm 128$ BP) ukazovaly na mladší dobu bronzovou, následné výstupy laboratoře v Groningen (GrN- $252472300 \pm 60 \mathrm{BP})$

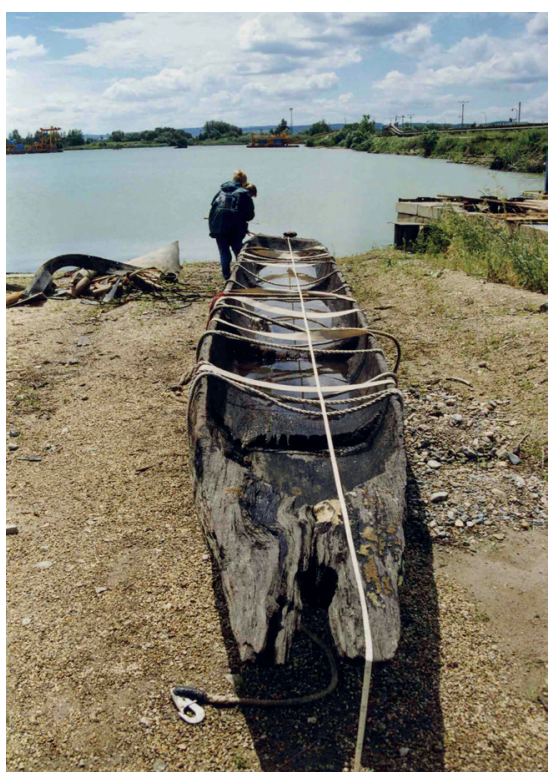

Obr. 6. Mohelnice „U Moravy“ 1999. Dokumentace lodi po vytažení na břeh. Foto archiv ACO.

Fig. 6. Mohelnice "U Moravy" 1999. Documentation of the boat after its extraction. Photo archive $A C O$. 


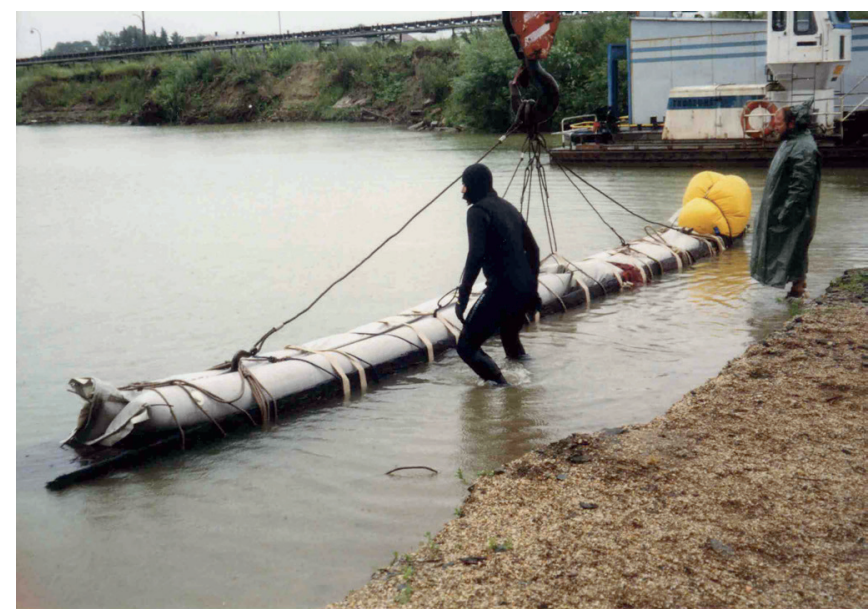

Obr. 7. Mohelnice „U Moravy“ 1999. Transport lodi na druhý břeh štěrkovny pomocí norných stěn a vyzvednut autojeřábem. Foto archiv ACO.

Fig. 7. Mohelnice "U Moravy" 1999. Transport of the boat to the other bank of the gravel pit reservoir using scumboards and recovery with heavy equipment. Photo archive $A C O$.

korigovaly stáří objektu do doby laténské, což potvrdila i dendrochronologická analýza, ${ }^{5}$ která upřesňuje datování do 3. nebo na přelom 4. a 3. století před n. 1. (281, resp. 301 BC, viz Tegel, Dvorská 2000). Společně se vzorkem z lodi byly analyzovány dva dubové kůly (K 3 a K 4) nalezené v jejím bezprostředním okolí (viz výše). Přestože neposkytly dostatečný počet letokruhů na samostatnou dataci, synchronizace s lodí se překrytím křivek potvrdila (Dvorská 2000). Nezávisle na těchto výsledcích byly vzorky z lodi i oba vzorky kůlů předány do laboratoře v Kyjevě, která přinesla prakticky shodné nebo velmi podobné výsledky (Kovalyukh 2000), ${ }^{6}$ čímž považujeme datování lodi i celé nálezové situace za potvrzené. Blízkost soudobé osady je navíc podepřena doklady sídliště ze střední doby laténské právě na lokalitě „Za cukrovarem“ (Stuchlík, Tichý et al. v tisku).

Objev monoxylu u Mohelnice na horním toku řeky Moravy představuje $\mathrm{v}$ našich archeologických poměrech nejseverněji položenou lokalitu a současně chronologicky dosud nejstarší dlabanou lod' z našeho území. Z geografického hlediska tvoří jakousi spojnici mezi horním Pomoravím a dolním Poodřím. V souvislosti s otázkami výměnného obchodu mezinárodního rozsahu naznačuje možnou cestu př́stupu $\mathrm{k}$ Baltu, která se

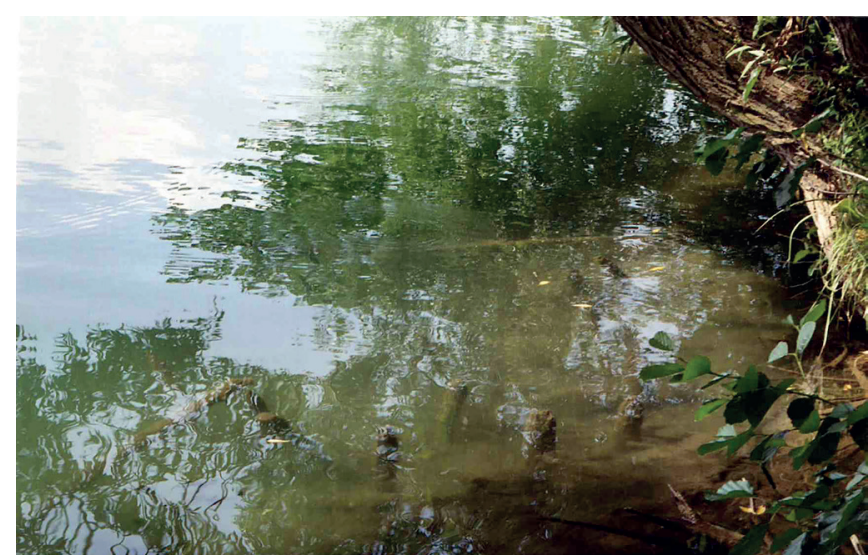

Obr. 8. Mohelnice „U Moravy“ 2001-2003. Struktura „nákolí“ v počtu minimálně 18-20 dřevěných kůlů (struktura C). Foto J. Peška.

Fig. 8. Mohelnice "U Moravy" 2001-2003. "Pile structure" consisting of at least 18-20 wooden piles (structure C). Photo by J. Peška. v prehistorii i historii objevuje hned několikrát. S přihlédnutím $\mathrm{k}$ velikosti a tvaru lodi nelze u mohelnického monoxylu vyloučit mimo jiné funkci obchodní, nákladní nebo chceme-li př́ímo kupecké lodi, přepravující zboží nejméně po vodách řeky Moravy. Je vysoce pravděpodobné, že byla objevena ve svém domovském úvazišti či malém přístavu, kde zůstala následkem nám blíže neznámé katastrofy „ukotvena“ nedaleko břehu tehdejšího koryta meandrující řeky až do svého objevení.

Jak ukázalo následné soustavné sledování okolí nálezu lodi, mohelnická štěrkovna, díky způsobu a množství zachování organických materiálů v našem prostředí zcela výjimečná a mimořádná archeologická lokalita, zatím nevydala všechna svá tajemství. V období let 2001-2003 se opakovaně uskutečnil terénní průzkumu břehu i dna mohelnického jezera jak v bezprostředním okolí místa nálezu monoxylu, tak také v širším okolí. ${ }^{7}$ Výsledkem bylo zjištění hned několika opracovaných dřevěných předmětů a struktur zatím neznámého stáří většinou pod vodní hladinou v pásmu zhruba do

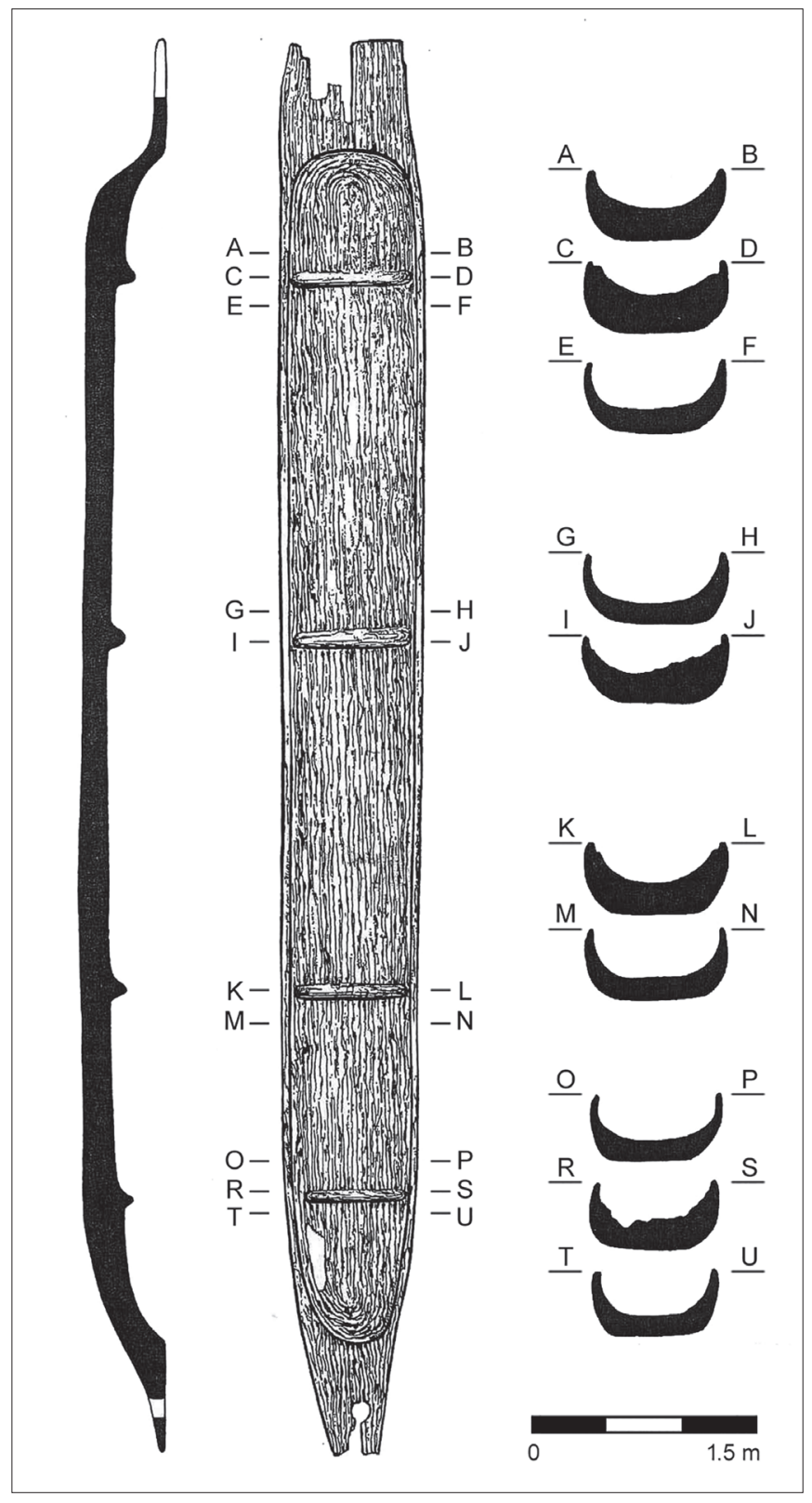

Obr. 9. Mohelnice „U Moravy“ 1999. Dubový monoxyl z doby laténské - půdorys a řezy. Kresba A. Pešková.

Fig. 9. Mohelnice "U Moravy" 1999. Oak monoxylon from the La Tène period ground plan and profiles. Drawing by $A$. Pešková. 


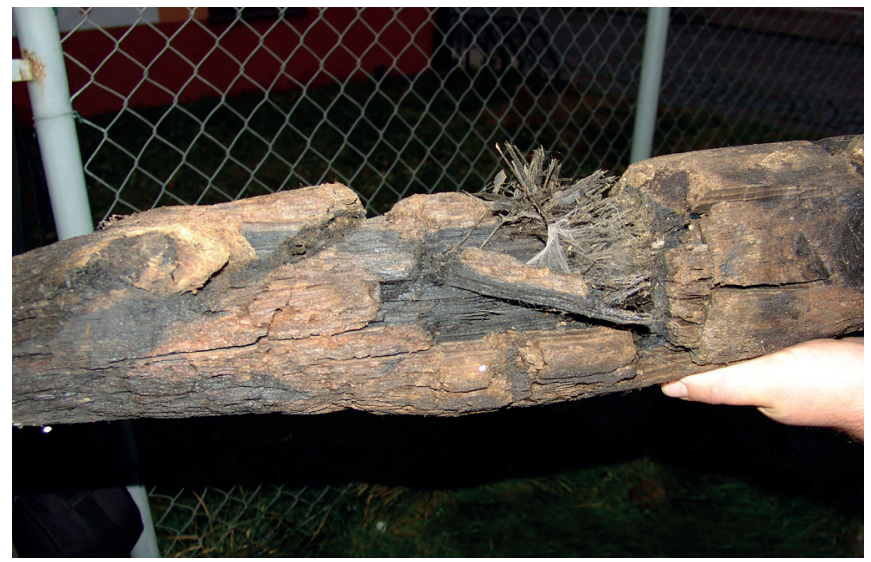

Obr. 10. Mohelnice „U Moravy” 1999. Stopy po úvazu na jednom z kůlů. Foto J. Peška.

Fig. 10. Mohelnice "U Moravy" 1999. Traces of mooring on one of the piles. Photo by J. Peška.

$5 \mathrm{~m}$ od břehu štěrkovny (dále od břehu je situace zničena těžbou). Asi 90 m od nálezu lodi směrem na SSZ vytáhli potápěči z větší hloubky jezera bohužel již sekundárně volně ložené minimálně 2 mohutné pravidelně ostře zahrocené kůly. Větší z nich (výška kolem 3,8 m, šířka $15 \mathrm{~cm}$ ), s mohutným kyjovitým zakončením, byl ve středové části opatřen asi $10 \mathrm{~cm}$ širokým zádlabem (obr. 11). ${ }^{8}$

Opačným směrem (na JJZ od lodi) asi $330 \mathrm{~m}$ byla v místech před zúženým přechodem $\mathrm{k}$ Moravičanskému jezeru pozorována těsně při břehu celkem 4 místa s dřevěnými strukturami (pracovně označena A-D, obr. 1). Struktura A působí dojmem útvaru sestaveného $\mathrm{z}$ několika zužujících se řad velmi tenkých kůlů a větví postavených (dnes šikmo ležících) do oblouku $\mathrm{v}$ délce min. $5 \mathrm{~m}$. Mezi slabými kůly a větvemi je rozmístěno nepravidelně několik mohutnějších kůlů kruhového nebo obdélného průřezu. Směrem do jezera je struktura odbagrována, v opačném směru zcela zjevně pokračuje pod břeh štěrkovny, který dnes tvoří vzrostlý lužní les (obr. 8). Šíŕka objektu nepřesahuje o mnoho $1 \mathrm{~m}$. Jen o několik metrů dále po břehu byly ve větší hloubce zaraženy šikmo minimálně 3 další kůly (struktura B). Těsně sousedící struktura $\mathrm{C}$ je tvořena soustavou alespoň 16-18 snad pravidelně (?) rozmístěných kůlů, z nichž některé, uvolněné těžbou, stojí ve vodě šikmo (obr. 12). Jejich

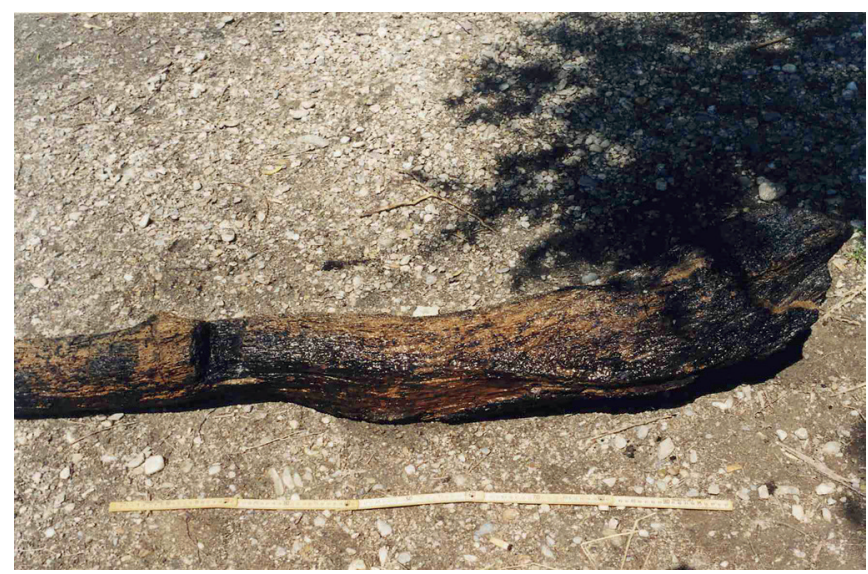

Obr. 11. Mohelnice „U Moravy“ 2001-2003. Mohutný dřevěný zahrocený kůl se zádlabem. Foto J. Peška.

Fig. 11. Mohelnice "U Moravy" 2001-2003. A massive wooden pointed pile with mortising. Photo by J. Peška.

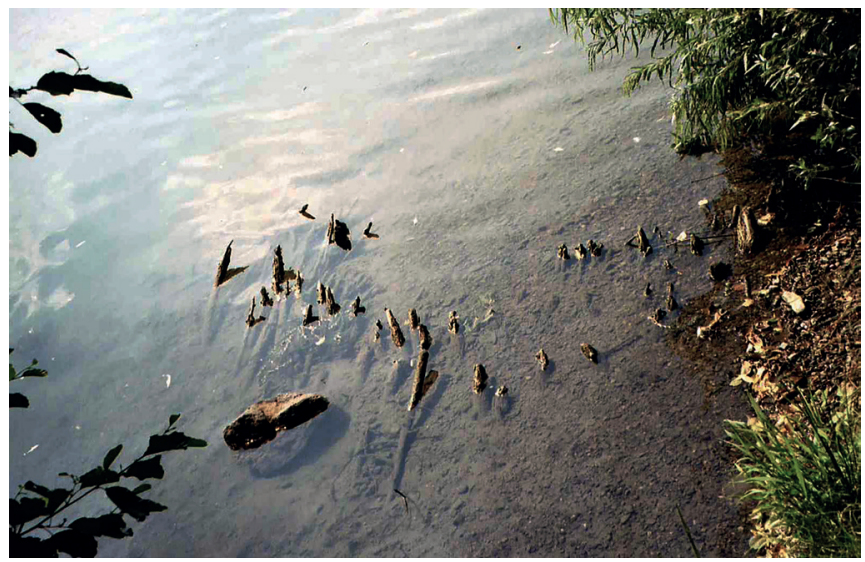

Obr. 12. Mohelnice „U Moravy“2001-2003. Šikmo položené řady tenkých kůlů a větví, mezi nimi větší opracované kůly (struktura A) - zařízení k lovu ryb (?) Foto J. Peška.

Fig. 12. Mohelnice U Moravy 2001-2003. Thin piles and branches lying askew with bigger worked piles among them (structure A) - an installation for fishing (?) Photo by J. Peška.

výška dosahuje cca 1,8 až 2 m, průměr kolem $8-10$ cm a spodní část je ostř̌e zahrocena pravidelnými záseky. Vedlejší obdobnou strukturu D tvoří 4 stojící a 2 ležící do obdélníka postavené kůly na ploše cca $2 \times 1,5 \mathrm{~m}$, mezi kůly se nacházejí 4 větší kusy lomového kamene (obr. 13, 14). Ten se objevuje pravidelně i u ostatních struktur.

Přesto, že prozatím neznáme stáří těchto objektů, lze u pravidelně rozmístěných konstrukcí ze zahrocených kůlů uvažovat o funkci základů nákolních staveb nebo př́mo o reliktech půdorysů původních kůlových konstrukcí menších (B, D) nebo větších (C) staveb. Zcela odlišná a svým způsobem výjimečná struktura A připomíná vzdáleně zařízení $\mathrm{k}$ lovu ryb, kde na konci zúženého koridoru byly umístěny vrše nebo vezírky. Taková zařízení známe z pravěku Evropy z více míst od mezolitu nebo neolitu, ale také např. $z$ doby halštatské nebo i pozdějších period (Andersen 1995; Köninger, Lübke 2001; Kaute et al. 2004). Na severu Německa (Kappeln ve Šlesvicku-Holštýnsku) se tento způsob lovu používá minimálně od středověku dodnes (obr. 15). Na rozdíl od Mohelnice jsou však často boční stěny splétány z větví, ale není to pravidlem. Konečná interpretace nejen tohoto objektu může následovat až po řádném prozkoumání a zdokumentování a samozřejmě také datování objevených dřevěných objektů.

Na podzim roku 2006 byl místními rybáři ohlášen nález několika dřevěných kůlů v prostoru nejsevernější mohelnické štěrkovny. Lokalita v trati „Za Moravou“ se nachází na SV břehu

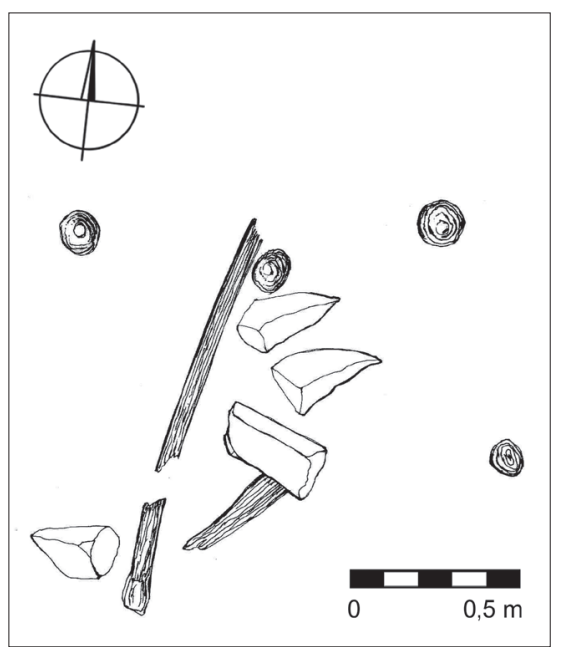

Obr. 13. Mohelnice U Moravy" 2001-2003. Struktura D - nálezová situace pod vodní hladinou. Foto J. Peška. Fig. 13. Mohelnice "UMoravy" 2001-2003. Structure D - find context beneath the water level. Photo by J. Peška. 


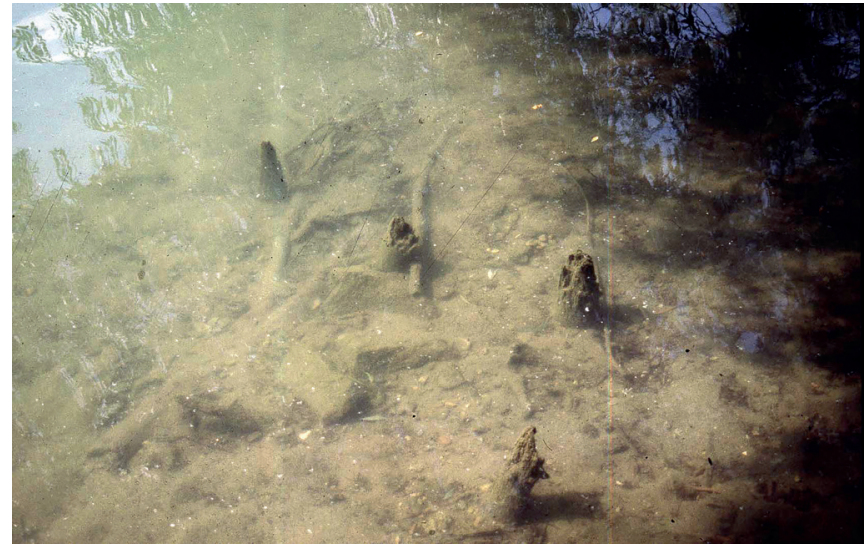

Obr. 14. Mohelnice „U Moravy“ 2001-2003. Stojící a ležící kůly s lomovým kamenem (struktura D). Foto J. Peška.

Fig. 14. Mohelnice "U Moravy" 2001-2003. Erect and laying stakes with quarry stone (structure D). Photo by J. Peška.

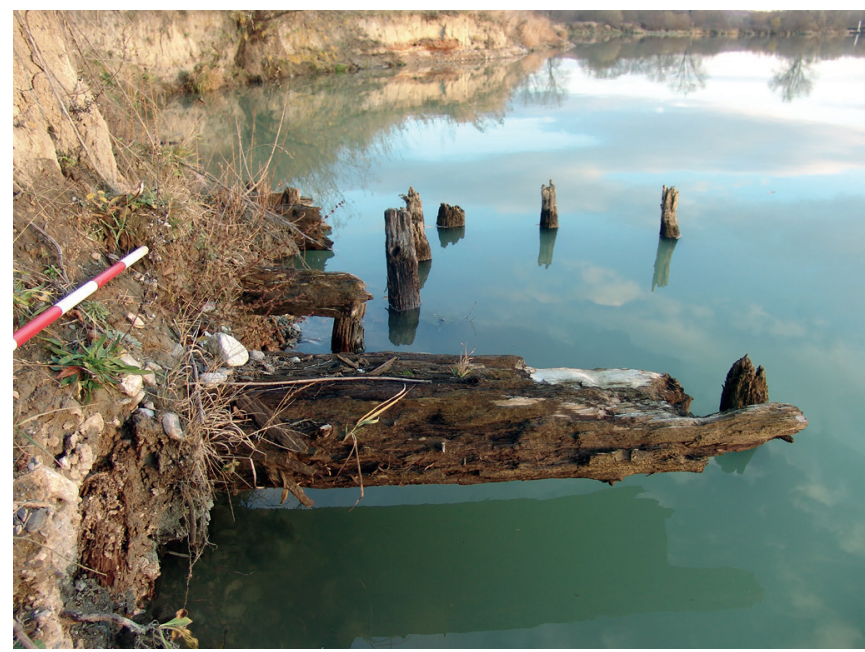

Obr. 16. Mohelnice „Za Moravou“ 2006. Mohutná dřevěná konstrukce mostu nebo lávky (2. polovina 16. století) na břehu štěrkovny (konstrukce 2). Foto V. Vránová. Fig. 16. Mohelnice "Za Moravou" 2006. A massive wooden bridge structure or a footbridge ( $2^{\text {nd }}$ half of the $16^{\text {th }}$ century) on the banks of the gravel pit reservoir (structure 2). Photo by V. Vránová.

nejvýše položené štěrkovny asi $1 \mathrm{~km} \mathrm{~S}$ od silnice MohelniceÚsov a asi 1,6 km SV od okraje města Mohelnice v blízkosti pravého břehu řeky Moravy (obr. 1). Při prohlídce lokality byla na SV břehu těžené štěrkopískovny zaregistrována přítomnost větší dřevěné konstrukce narušené těžbou. Zbytky dřev se nacházely pod cca 2-3 m mocnými povodňovými hlínami na úrovni štěrkopískového podloží jednak v blízkosti břehu ve vodě, jednak vyčnívaly ze břehu těsně nad vodou (konstrukce 2 ). Další část konstrukce byla obnažena několik metrů od břehu směrem k řece v místech jakési umělé „kapsy“, vzniklé v důsledku lokální těžby povodňových hlín nebo vodní erozí a zalité částečně vodou (konstrukce 1). Při bližším ohledání vyšlo najevo, že se jedná o totožnou velmi mohutnou dřevěnou konstrukci o délce několika metrů. Tvořena byla původně $4-5$ řadami stojících kůlů překrytých v podélné ose mohutnými nestejně širokými fošnami (obr. 16). Nejrozměrnější fošna byla v jednom místě opatřena výřezem, do něhož ještě dnes jedna $\mathrm{z}$ nich dobře zapadá. Šíŕku objektu lze odhadovat na 2-3 m. V místě „kapsy“ sestávala silně porušená konstrukce, kromě jedné zachovalé řady kůlů

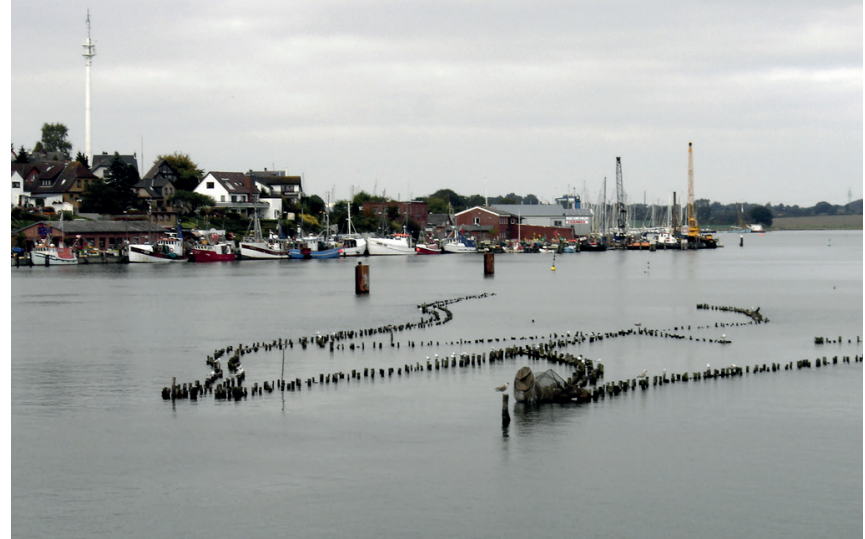

Obr. 15. Kappeln, Schleswig-Holstein/D 2006. Zařízení k lovu ryb v mořské zátoce. Foto J. Peška.

Fig. 15. Kappeln, Schleswig-Holstein/D 2006. Installation for fishing in a sea bay. Photo by J. Peška.

s pravidelnými rozestupy (cca $1 \mathrm{~m}$ ), z několika příčně položených trámů, z nichž 2 se zachovaly včetně detailu původního spojení (obr. 17). Jak ukázal dosavadní archeogeofyzikální průzkum, těleso pokračuje $\mathrm{v}$ délce minimálně 15-20 m směrem k řece. Lineární průběh vykazuje také menší anomálie probíhající paralelně po jeho Z boku, podobných anomálií bylo v okolí naměřeno více (Hašek et al. 2007).

Necelých $5 \mathrm{~m}$ západně od konstrukce jsme v profilu břehu jezera zaznamenali velkou kumulaci menších opracovaných kůlů (průměr mezi 10-20 cm) a mezi nimi množství lomového kamene různé velikosti (obr. 18). Kůly budí dojmem, že byly postaveny v několika řadách (konstrukce 3). Celá situace je však silně narušena erozí břehu štěrkovny. Nesmírně zajímavé jsou výsledky dendrologické analýzy, ${ }^{9}$ která v odebraných vzorcích shledala dubové nosné kůly, dubové i jedlové podélné fošny, zatímco příčné trámy byly zhotoveny z jedle bělokoré. $V$ kumulaci malých kůlů byl prozatím jasně identifikován topol.

Z řady dubových nosných kůlů konstrukce 1 byl odebrán vzorek na dendrochronologické datování. Výsledek hovoří o stáří stromu do roku 1543, kdy k jeho pokácení mohlo dojít v letech 1547-1560, doložená oprava nás zavádí do roku 1645 (Rybníček, Přemyslovská 2006; Peška, Vránová eds. 2016, 25).

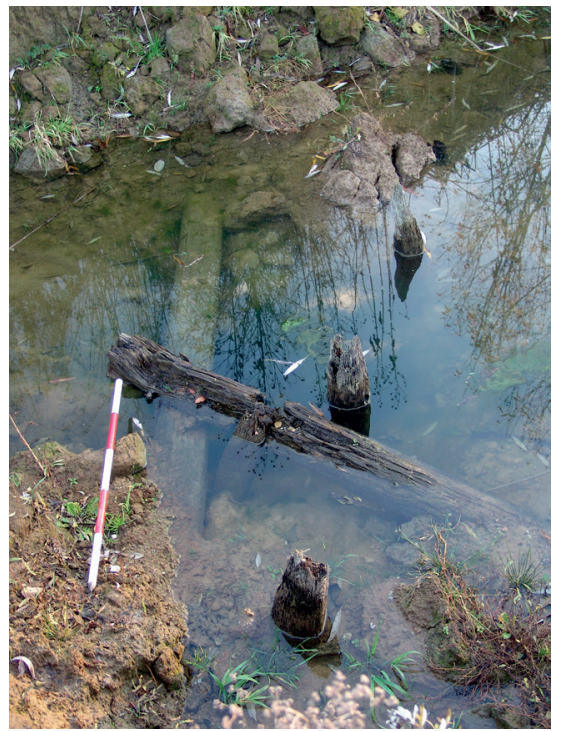

Obr. 17. Mohelnice

Za Moravou“ 2006.

Pokračování dřevěného mostu nebo lávky

(2. polovina 16. století)

s řadou nosných kůlı̊

a detailem spojen

(konstrukce 1).

Foto V. Vránová.

Fig. 17. Mohelnice

"Za Moravou" 2006. Continuation of the bridge or footbridge $\left(2^{\text {nd }}\right.$ half of the $16^{\text {th }}$ century) with a row of supporting piles and a detail of a connection (structure 1). Photo by V. Vránová. 


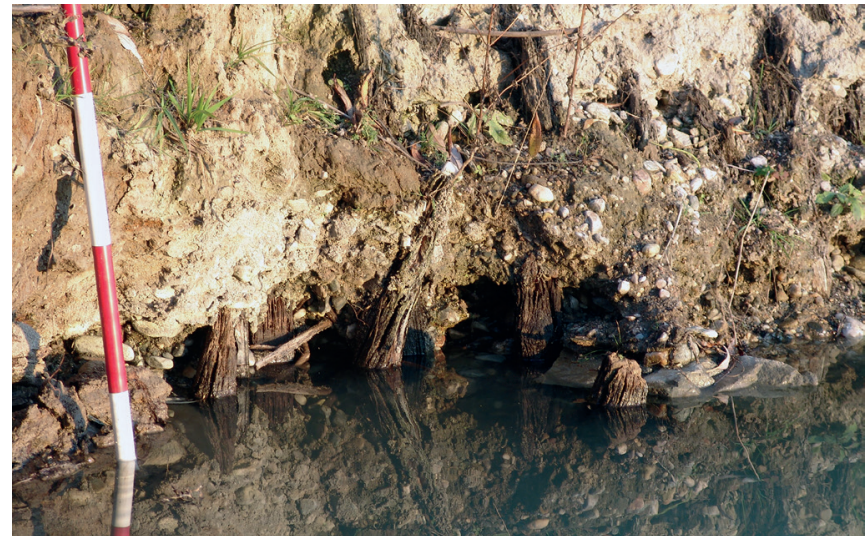

Obr. 18. Mohelnice „Za Moravou“ 2006. Řady drobných kůlů v erodujícím břehu štěrkovny (konstrukce 3). Foto V. Vránová.

Fig. 18. Mohelnice "Za Moravou" 2006. Rows of small piles in the eroding bank of the gravel pit reservoir (structure 3). Photo by V. Vránová.

Nejmohutnější konstrukci (č. 1 a 2) můžeme dnes označit za hatovou cestu, prríp. menší most nebo lávku z 2. poloviny 16. století, překlenující tehdejší meandr řeky Moravy na spojnici mezi Třeštinou a Mohelnicí nedaleko jednoho z mlýnů (Untere Mühle). Existence původní cesty právě v těchto místech je spolehlivě doložena na mapách I. vojenského (josefského) mapování z let 1764-1768 a 1780-1783. Díky výsledkům geofyzikálního měření, ale i svědectví místních pamětníků, ${ }^{10}$ nelze vyloučit přítomnost dalších a mnohem rozsáhlejších dřevěných objektů sloužících například $\mathrm{k}$ překonání místy bahnitého a podmáčeného terénu v nivě řeky Moravy. Na základě těchto nesmírně zajímavých zjištění by byl jejich podrobný výzkum v blízké budoucnosti velice důležitý.

Nejen závažné starší, ale především nejnovější doslova senzační archeologické nálezy napovídají, že v případě mohelnické štěrkovny a jejího nejbližšího okolí máme co do činění se zcela mimořádnou a v našich poměrech těžko srovnatelnou lokalitou přinejmenším evropského významu, která není po archeologické stránce ještě ani zdaleka vyčerpána, a jejíž další výzkum by mohl přinést nejeden závažný poznatek a překvapení.

\section{Poznámky}

1 Na záchraně unikátního předmětu se kromě již jmenovaných podílel také celý kolektiv zaměstnanců Vlastivědného muzea v Olomouci a jeho Archeologického centra, Technické služby města Olomouce, firma Mrázek Brno, Bezpečnostní agentura Kytlica.

2 Ke konzervaci byla použita metoda napouštění nízkomolekulárním PEG 200 tzv. studenou cestou s následným vysoušením a nátěrem pomocí vysokomolekulárního PEG 4000. Proces konzervace nebyl do těchto dnů ukončen.

3 Za určení děkuji srdečně Ing. J. Kynclovi, Botanický ústav AV ČR Praha, pracoviště Brno.

4 Posudek není, bohužel, doposud k dispozici.

5 Dendrochronologický průzkum provedli dr. J. Dvorská (Archeologický ústav AV ČR, Brno), dr. M. Krąpiec (Dendrochronologická laboratoř Univerzity hornicko-hutnické v Krakově) a W. Tegel (Dendrochronologisches Labor des Landesdenkmalamt Baden-Württemberg).

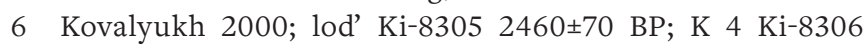
$2250 \pm 70$ BP; K 3 Ki-8307 2320 80 BP (za laskavé určení vzorků jsem autorovi velice zavázán).

7 Výzkumu pod vodní hladinou se v roce 2001 ujali bratři M. a S. Salašové, za což jim náleží můj vřelý dík.
8 Nálezy byly vráceny do vod jezera.

9 Za zatímní určení druhů dřevin jsem díkem zavázán Ing. H. Vavrčíkovi, PhD. z Ústavu nauky o dřevě, Fakulta lesnická a dřevařská, Mendlova zemědělská a lesnická univerzita v Brně.

10 Podle svědectví místních obyvatel si lidé ještě v nedávné minulosti „mnoho takových zahrocených kůlů a dřev z jezera odváželi po celých fůrách domů na topení“...

\section{Literatura}

Andersen, S. H. 1995: Coastal adaption and marine exploitation in Late Mesolithic Denmark - with special emphasis on the Limfjord region. In: A. Fischer (ed.): Man and Sea in the Mesolithic. Coastal settlement above and below prezent sea level. Proceedings of the International Symposium, Kalundborg, Denmark 1993. Oxbow Monograph 53. Oxford: Oxbow, 41-66.

Arnold, B. 1995: Pirogues monoxyles d'Europe centrale: construction, typologie, évolution. Archéologie neuchâteloise 20. Neuchâtel: Musée cantonal d'archéologie.

Babiński, L. 1999: The Two-step stabilization of the dug-out canoe from Lewin Brzeski. In: L. Reinprecht (ed.): Rekonštrukcia a konzervácia historického dreva '99. Zvolen: Technická univerzita vo Zvolene, 189-194.

Barthez, J., Hiron, X., Arnold, B., Marquis, P., Velay, P. 1999: Historic and conservation treatment of then neolithic dug-out canoe from the Bercy site in Paris. In: L. Reinprecht (ed.): Rekonštrukcia a konzervácia historického dreva'99. Zvolen: Technická univerzita vo Zvolene, 183-187.

Dvorská, J. 2000: Závěrečná zpráva. Mohelnice - štěrkovna. Rkp. závěrečné zprávy. Uloženo: Archeologické centrum Olomouc.

Filipowiak, W. 1995: Die Bedeutung der Binnenschiffahrt im Odergebiet. Germania 73, 481-493.

Fugazzola Delpino, M. A., Mineo, M. 1995: La piroga neolitica del lago di Bracciano („La Marmotta 1“). Bullettino di Paletnologia Italiana 86, 197-266.

Hašek, V., Maštera, L., Peška, J., Tomešek, J. 2007: Zpráva o archeogeofyzikální prospekci na akci Mohelnice, trat’ „Za elektrárnou“ - těžba štěrkopísku I. etapa, Brno. Rkp. zpráva. Uloženo: Archeologické centrum Olomouc.

Hrubý, V. 1949: Staroslovanské čluny na našem území. Z dávných věků 2, 119-135.

Kaute, P., Labes, S., Schindler, G. 2004: Ein kaiserzeitlicher Fischzaum im Greiswalder Museumshafen. Archäologische Berichte aus Mecklenburg-Vorpommern 11, 24-37.

Köninger, J., Lübke, C. 2001: Bemerkungen zur vorgeschichtlichen Fischerei im westlichen Bodenseegebiet und in Oberschwaben. Nachrichtenblatt Arbeitskreis Unterwasserarchäologie 8, 67-82.

Kovalyukh, N. N. 2000: Resultaty radiouglerodnovo datirovania. Rkp. zpráva. Uloženo: Archeologické centrum Olomouc.

Kučerová, I., Peška, J. 2004: Monoxyl z Mohelnice. In: Konzervace vodou nasyceného dřva. Odborný seminár: 22. duben 2004, Národní muzeum. Praha: Společnost pro technologie ochrany památek, 32-38.

Novotný, B. et al. 1986: Encyklopédia archeológie. Bratislava: Obzor.

Peška, J. 1999a: Unikátní archeologický objev u Mohelnice. Střední Morava 9, 4-8.

Peška, J. 1999b: Unikátní nález monoxylu u Mohelnice. Zprávy Vlastivědného muzea v Olomouci 278, 74-78.

Peška, J. 2000: Mohelnice (okr. Šumperk). Přrehled výzkumů 41(1999), 124-126.

Peška, J., Kučerová, I. 2002: Monoxyl z Mohelnice, jeho nález a konzervace. In: Sborník z konzervátorského a restaurátorského semináře konaného ve dnech 17.-19. zář́i 2002 v Pardubicích. Brno: Technické muzeum v Brně, 24-30. 
Peška, J., Vránová, V. (eds.) 2016: Věda rýče promluvila. Archeologické centrum Olomouc 1995-2015, stř́ipky. Olomouc: Archeologické centrum Olomouc.

Poláček, L., Marek, O., Skopal, R. 2000: Holzfunde aus Mikulčice. In: L. Poláček (Hrsg.): Studien zum Burgwall von Mikulčice. Band 4. Spisy Archeologického ústavu AV ČR Brno 18. Brno: Archäologisches Institut der Akademie der Wissenschaften der Tschechischen Republik Brno, 177-302.

Rogers, J. S. 2004: Logboats of the Moravian Gate: Monoxyl Dugout Vessels from Central Europe. Rkp. MA dissertation. East Carolina Univerzity. Faculty of the Department of history. Uloženo: East Carolina University, Greenville. Dostupné také z: https://thescholarship.ecu.edu/handle/10342/6657.

Rybníček, M., Přemyslovská, E. 2006: Závěrečná zpráva. Mohelniceštěrkovna (kůl z konstrukce 1). Rkp. zpráva Dub. Uloženo: Archeologické centrum Olomouc.

Stuchlík, S., Tichý, R. et al. v tisku: Mohelnice. Polykulturní pravěké sídliště. Spisy Archeologického ústavu AV ČR Brno. Brno: Archeologický ústav AV ČR, Brno.

Šilhová, A., Špaček, J. 2004: Monoxyl z Čelákovic a jeho konzervace. In: Sborník přednášek z odborného semináře Společnosti pro technologii ochrany památek. Praha: Společnost pro technologii ochrany památek, 29-31.

Špaček, J. 2002: Nový nález monoxylu ze středních Čech - předběžné sdělení. Rekonstrukce a experiment $v$ archeologii 3, 170-171.

Tegel, W., Dvorská, J. 2000: Bericht zur dendrochronologischen Untersuchungen des Einbaumes aus Mohelnice (Mähren). Rkp. zpráva. Uloženo: Archeologické centrum Olomouc.

Tichý, R. 2002: Dlabané čluny. Př́íspěvek experimentální archeologie k poznání dávné vnitrozemské plavby. Rekonstrukce a experiment $v$ archeologii 3, 40-69.

\section{Summary}

The latest archaeological finds from the Mohelnice gravel plant further emphasize the exceptional character of this site. Approximately $800 \mathrm{~m}$ to the east from the site (Fig. 1) a remarkable discovery of a logboat oak monoxylon from the La Tène period was made in June 1999 (dendrochronological age: 281 or 301 BC) The rear section of the vessel was trapped in the river mud. The logboat was associated with two rows of wooden piles, which dating confirms to be the same age (Fig. 4). One of them was bearing very distinct traces of mooring (Fig. 10). The archaeological context is consistent with the idea that the boat has been discovered in its original context (a wharf/port), where it has remained as a result of an unknown disaster. The boat $(10.5 \times 1.05 \times 0.60 \mathrm{~m})$ is of a slightly conical shape with an asymmetrically pointed bow and a small, oblong foot board at the stern; it is segmented by 4 transverse shoulders (Fig. 9); the thickness of the preserved wood varies between 3.1 and $18 \mathrm{~cm}$. Its weight is $1094 \mathrm{~kg}$, thickness is $17.5 \mathrm{~cm}$, the cargo capacity $1077 \mathrm{~kg}$; it could carry up to 18-crew members (Rogers 2004). It is the northernmost and the oldest Moravian find of its kind. Its age is corroborated both by radiocarbon method ( $\mathrm{GrN}-25247$ $2300 \pm 60 \mathrm{BP}$ ) and dendrochronologically, including samples taken from two poles ( $\mathrm{K} 3$ and 4). The Mohelnice monoxylon is interpreted as a trading, cargo, or merchant boat transporting goods on the Morava River with potential access to the Silesian Oder River area.

Subsequent research of the find surroundings has yielded a number of new discoveries of wooden structures (A-D), some of which probably constitute ground plans of pile structures (B-D) of various sizes. Structure A (rows of piles, thin piles and branches laying askew across the bow: Fig. 12) resembles fishing equipment as we know it from the Mesolithic, Neolithic or
Hallstatt periods (Andersen 1995; Köninger, Lübke 2001; Kaute et al. 2004) and practically until today (Kappeln; Fig. 15).

In the northernmost gravel pit reservoir (the "Za Moravou" site; Fig. 1) a gradually eroding, massive bridge structure, or a footbridge from the $2^{\text {nd }}$ half of the $16^{\text {th }}$ century was measured (dendrochronologically), spanning the meander of the river at the road intersection from Třeština to Mohelnice not far from a water mill (Fig. 16-18).

\section{Kontakt:}

Jaroslav Peška

Archeologické centrum Olomouc

U Hradiska 42/6

CZ-779 00 Olomouc

peska@ac-olomouc.cz 